\title{
Biological Characterization of Trypanosoma cruzi Strains
}

\author{
Rafael A Martínez-Díaz/+ , José A Escario*, Juan J Nogal-Ruiz*, \\ Alicia Gómez-Barrio*
}

\begin{abstract}
Departamento de Medicina Preventiva (Parasitología), Facultad de Medicina, Universidad Autónoma de Madrid, C/Arzobispo Morcillo s/n, 28029 Madrid, España *Departamento de Parasitología, Facultad de Farmacia, Universidad Complutense de Madrid, Madrid, España
\end{abstract}

Biological parameters of five Trypanosoma cruzi strains from different sources were determined in order to know the laboratory behaviour of natural populations. The parameters evaluated were growth kinetics of epimastigotes, differentiation into metacyclic forms, infectivity in mammalian cells grown in vitro and parasite susceptibility to nifurtimox, benznidazole and gentian violet. Differences in transformation to metacyclic, in the percentage of infected cells as well as in the number of amastigotes per cell were observed among the strains. Regarding to pharmacological assays, $Y$ strain was the most sensitive to the three assayed compounds. These data demonstrate the heterogeneity of natural populations of T. cruzi, the only responsible of infection in humans.

Key words: Trypanosoma cruzi - strains - characterization

Trypanosoma cruzi is the etiologic agent of Chagas disease, a frequently fatal illness affecting the heart and gastrointestinal systems. An estimated 16 to 18 million people in Latin America and 50,000 to 100,000 people in the United States are infected with this pathogen (WHO 1991). A striking feature of $T$. cruzi is its heterogeneity in relation to biological properties. Differences in growth rates, infectivity, tissue tropism, antigenic composition, virulence and morbility in animal models and susceptibility to immune sera and chemotherapeutic drugs have been reported in parasite isolates (Andrade et al. 1975, 1985, Brener et al. 1976, De Castro \& De Meirelles 1987, Melo \& Brener 1978, Neal \& Van Bueren 1988, Roval et al. 1990). In humans, a broad spectrum of clinical presentations in Chagas disease is observed, possibly reflecting the heterogeneity among $T$. cruzi isolates and/or genetic differences in the immune response of the host (Brener 1980).

Early studies also revealed substantial isozymic variability among isolates, defining three major groups or zimodemes (Miles et al. 1980). Characterization of different classes of parasites has been also achieved by studying restriction fragment length polymorphism of kDNA (Morel et al. 1980). Therefore, both biological and genetic char-

${ }^{+}$Corresponding author. Fax: +34-1-397.5353. E-mail: rafael.martinez@uam.es

Received 17 February 2000

Accepted 9 August 2000 acteristics have shown a marked polymorphism in natural populations of $T$. cruzi.

Nowadays, the advances in the fields of molecular biology and genetic are allowing to elucidate some of the reasons for such a variability in the biological behaviour of $T$. cruzi strains. So, Allaoui et al. (1999) have applied genetic manipulations techniques to ascertain the biological functions of $T$. cruzi Tc52 protein. This is a recently identified protein (Ouaissi et al. 1995a) encoded by a single pair of allelic genes, that increases during the stationary growth phase of epimastigotes cultures, with interesting enzymatic and immunosuppressive activities (Ouaissi et al. 1995b, Fernandez-Gómez et al. 1998).

Although the possibility of assays with transformed parasites by gene manipulation is now a reality, the true is that the heterogeneous populations that are maintained in nature are the only responsible of infection in humans and a large number of other mammalian species.

By this reason, the aim of this work is to know biological characteristics of these natural populations of T. cruzi, including growth kinetics of epimastigotes, metacyclogenesis in Grace medium, infectivity in mammalian cells grown in vitro and finally, the susceptibility to nifurtimox, benznidazole and gentian violet. These characteristics can be considered as natural heterogeneity markers and may have important implications in the clinic features of Chagas disease.

\section{MATERIALS AND METHODS}

T. cruzi strains - Five strains of T. cruzi from different biological and geographic origins were 
studied. Bolivia strain (Funayama \& Prado Junior 1974) was isolated from Triatoma infestans in Vitichi (Bolivia) and it causes high parasitaemias and moderate mortality in mice. RAL strain (Ribeiro et al. 1993) was also isolated from $T$. infestans in São Paulo (Brazil). GM strain (Prado Junior et al. 1992a) from Brazil was isolated by xenodiagnostic from Felis yagouaroundi coming from Mato Grosso; this strain causes high parasitaemia and mortality in mice. MC strain (Prado Junior et al. 1992b) was isolated in Brazil from Chrysocyon brachyurus, and it reaches moderate parasitaemia and mortality in mice. Finally, Y strain (Silva \& Nussenzweig 1953) was isolated from an acute human case coming from Marília (São Paulo, Brazil) in 1950; this strain is responsible of low parasitaemia but high mortality in mice.

Groups of NMRI mice were inoculated with every strain. After exsanguination, blood of infected mice was cultured in glass tubes with $5 \mathrm{ml}$ LIT medium (10\% heat-inactivated fetal calf serum) and two subcultures were performed in this medium before beginning the assays.

Growth curves - To determine the growth rates of the parasite strains, $5 \times 10^{5}$ epimastigotes $/ \mathrm{ml}$ were seeded in LIT medium supplemented with $10 \%$ FCS and maintained at $28^{\circ} \mathrm{C}$. Number of epimastigotes were assessed in a hemocitometer.

Metacyclogenesis - Metacyclogenesis was achieved in Grace medium (Grace 1962) supplemented with $10 \%$ FCS. Supernatants from LIT axenic cultures, containing live forms, were collected after centrifugation and then washed with fresh LIT medium. Nine millions of trypanosomes/ $\mathrm{ml}$ were seeded in glass tubes with $5 \mathrm{ml}$ Grace medium. Metacyclic trypomastigotes were observed from $48 \mathrm{~h}$ onwards. Aliquots of the supernatants were fixed and stained with Giemsa to follow the kinetics of differentiation into metacyclic forms.

Infectivity to cultured mammalian cells - Two cell lines were used: Vero fibroblasts, maintained in Minimal Essential Medium (20\% FCS) and J774 macrophages maintained in RPMI medium (20\% FCS). In both cases 15,000 cells/well were seeded on sterile round coverslips placed in 24-well plates. Then 150,000 trypomastigotes from Grace medium were added to each well, giving a final volume of $2 \mathrm{ml}$. Metacyclic trypomastigotes were allowed for $24 \mathrm{~h}$ to invade cells; culture medium was removed and fresh medium were added. Infected cells were incubated at $37^{\circ} \mathrm{C}$ in $5 \% \mathrm{CO}_{2}$. Cells grown on coverslips were fixed with methanol and stained with Giemsa stain for microscopic counts of number of infected cells and number of amastigotes per infected cell.
Susceptibility to chemotherapeutic agents Parasite sensitivity to nifurtimox, benznidazole and gentian violet was assayed on epimastigote cultures as previously described (Herrero et al. 1992). Five concentrations ranging from 100 to $0.01 \mu \mathrm{g} / \mathrm{ml}$ were used. Growth indexes, growth percentages and reduction percentages respect to control untreated cultures were calculated as follows:

Growth index (G.I.) $=\frac{\text { Final number of parasites }}{\text { Initial number of parasites }}$

Growth percentage (G.P.). Only when G.I. experimental group $>1$

$$
\text { G.P. }=\frac{\text { G.I. experimental group }}{\text { G.I. control group }} \times 100
$$

Reduction percentage (R.P.). Only when G.I. experimental group $<1$

$$
\text { R.P. }=100-\left(\frac{\text { G.I. experimental group }}{\text { G.I. control group }}\right) \times 100
$$

\section{RESULTS}

The growth rates of the parasite strains measured for 22 days of culture were not different (Fig. 1). All strains achieved a growth peak over 20 millions epimastigotes $/ \mathrm{ml}$ between days 9 th and 11 th of culture, with the only exception of GM strain, that delayed its peak at day 16th. The stationary phases were around 15-20 millions of epimastigotes/ml for Bolivia, GM, MC and Y strains, while RAL strain only reached 10 millions.

The transformation of $T$. cruzi epimastigotes to the mammalian infective metacyclic trypomastigotes showed more variability (Fig. 2), ranging from counts of $10(\mathrm{GM})$ to 3 (RAL, MC and $\mathrm{Y}$ ) millions of trypomastigotes $/ \mathrm{ml}$. In all cases, the higher levels of trypomastigotes were found after day 9th (Table II).

Assays of infectivity to Vero cells and J774 macrophages revealed differences for both RAL and GM strains (Fig. 3). Also, as can be seen in Figs 4 and 5, all the strains, with the only exception of RAL, completed their intracellular multiplication in six days, releasing the second generation of trypomastigotes responsibles of new infections in healthy cells.

Finally, differences in sensitivity to nifurtimox, benznidazole and gentian violet could be appreciate among strains (Table I).

\section{DISCUSSION}

Chagas disease has a broad variety of clinical presentations that may be the result either of heterogeneity among the $T$. cruzi isolates or of the host immune response (Brener 1980). Regarding 


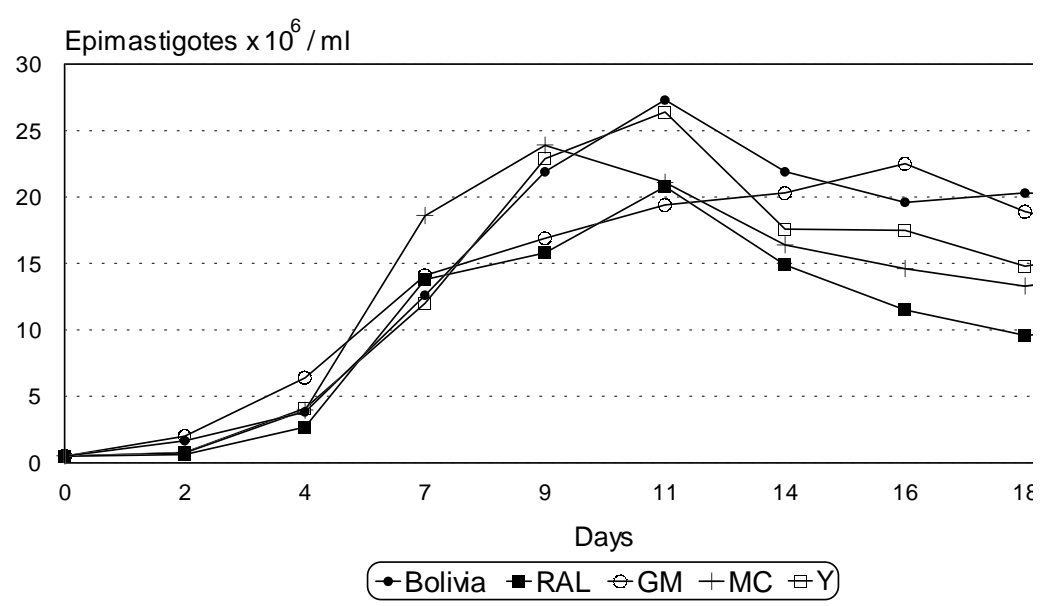

Fig. 1: in vitro growth curves of Trypanosoma cruzi in LIT medium.

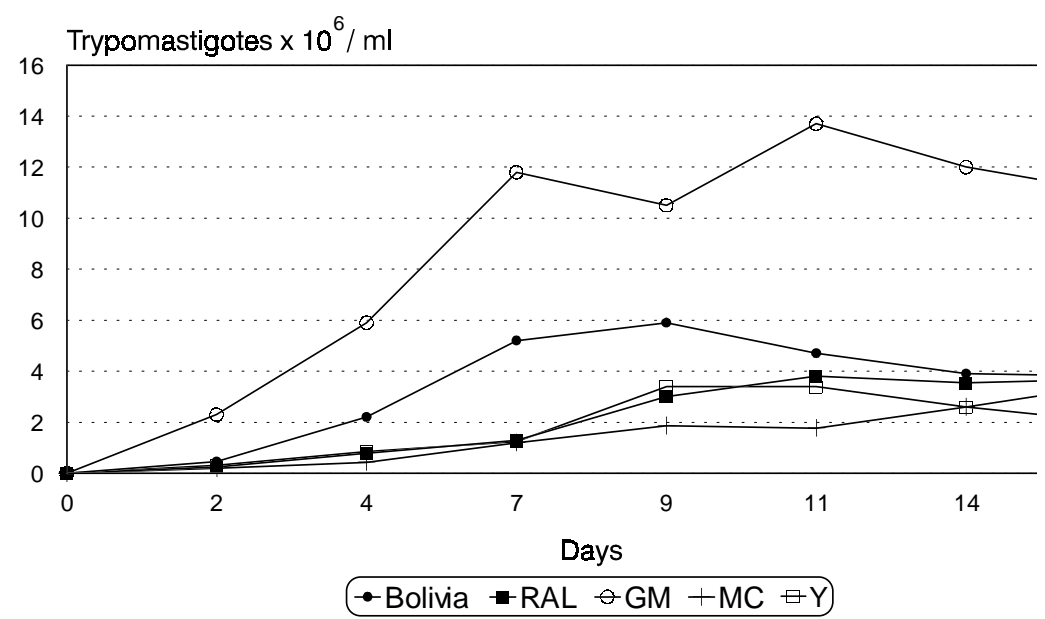

Fig. 2: kinetics of morphological transformation of Trypanosoma cruzi. Number of trypomastigotes was determined by differential counting of Giemsa stained smears.

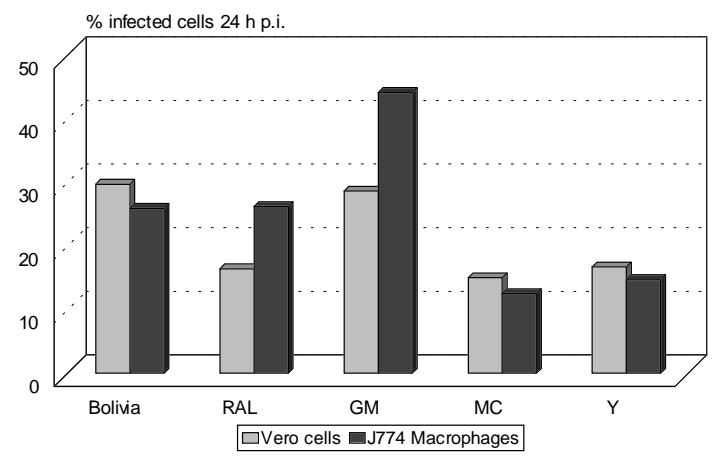

Fig. 3: infection of culture-derived metacyclic trypomastigotes to cell cultures. to parasite, the infecting strain is a substantial determinant of the evolution of the disease (Montamat et al. 1999).

The diversity in the clinical expression of infection has estimulated interest in studying biological, biochemical and genetic differences among strains. Analysis of natural populations of T. cruzi using either isoenzymes or kDNA sequences as genetic markers has revealed a basic clonal structure (Tibayrenc et al. 1986, Tibayrenc \& Ayala 1988). Miles and coleagues (Miles et al. 1978, Ready \& Miles 1980) defined three zymodemes termed Z1, Z2 and Z3, based on the analysis of stocks from the north and northeast of Brazil. When 


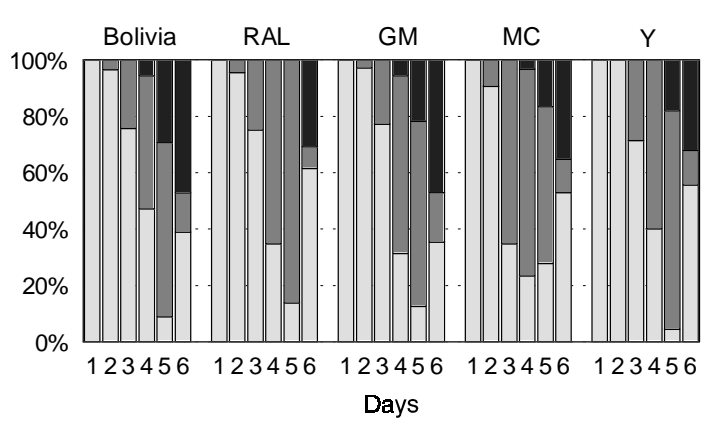

Fig. 4: rate of Vero cells infected with less than five amastigotes of Trypanosoma cruzi ( $\square$ ), 5-50 amastigotes ( $\square$ ) and more than 50 amastigotes

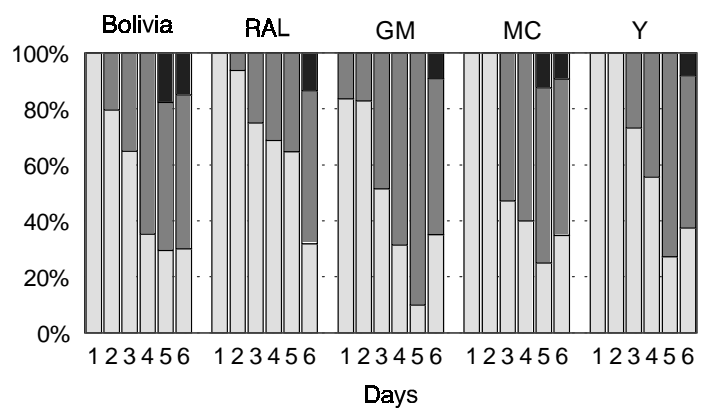

Fig. 5: rate of $\mathbf{J} 774$ macrophages infected with less than five amastigotes of Trypanosoma cruzi ( $\square$ ), 5-50 amastigotes $(\square)$ and more than 50 amastigotes $(\square)$.

random amplification of polymorphic DNA (RAPD) is applied to the study of parasite populations, Steindel et al. (1993) concluded that there is significant genetic variation within zymodemes. Furthermore, different groups of investigators (Carreño et al. 1987, Solari et al. 1992, Tibayrenc \& Ayala 1987, Montamat et al. 1999) have demonstrated a close relation between zymodemes and schizodemes, suggesting that nuclear structural genes coding for enzymes and extranuclear DNA (kDNA) have had a parallel evolution.

Because of such variability, the main objective of this work was to know the diversity in the behaviour of $T$. cruzi isolates. Several parameters, selected as natural markers of biological variability have been assessed.

The growth of epimastigotes in LIT medium shows similar dynamics. By contrast, the ability of in vitro metacyclogenesis is clearly higher for GM strain epimastigotes that achieved $40 \%$ of transformation to trypomastigotes. Seven to nine days was the time required for the other strains to reach the maximum number of trypomastigotes, results according to Osuna-Carrillo et al. (1979).
In order to know if the variability of the natural populations of $T$. cruzi affect to the intracellular development of parasites, 10 motile trypomastigotes per cell (both fibroblast or macrophage) were added to infect mammalian cell cultures. As the proportion of infected cells is directly related to the number of metacyclic forms (Schenkman et al. 1988), we previously stablished the 10:1 rate between parasites and cells to compare the intrinsic ability of the strains to infect vertebrate cells. Moreover, the host cellular type can influence on parasitic levels (Ley et al. 1988, Schenkman et al. 1988); there are tissues and cell lines specially susceptible to $T$. cruzi infection while others seldom suffer it. So, we have found the major differences for GM and RAL strains; both of them infect better $\mathbf{J 7 7 4}$ macrophages than Vero fibroblasts.

Since the only replicative forms in $T$. cruzi life cycle in the vertebrate host are intracellular amastigotes, the cell infection ability of a strain could be related to a higher parasitaemia in mice. That is true for GM and Bolivia strains, that show in our experiences high cell infection rates, and both reach high parasitaemias in mice (Prado Junior et al. 1992a, Atienza 1994) with 39,000 and 49,000 trypanosomes/ml blood, respectively. Nevertheless, the behaviour is not related to mortality; so, while GM kills $100 \%$ of experimentally infected mice, Bolivia only causes death of the $83 \%$ of the animals (Atienza 1994). Virulence seems to be an intrinsic property of each strain (Kagan et al. 1966, Barbosa et al. 1988); in fact, some strains usually maintained in laboratories are characterized as strains with high pathogenicity and low parasitaemias (Y strain) or strains with low pathogenicity and high parasitaemias (Bolivia) (Silva \& Nusenzweig 1953, Funayama 1974). In the same way as pathogenicity is not related to parasitaemia, the infectivity to cultured mammalian cells could not be a consequence of the natural pathogenicity of a strain (Atienza 1994). According to previous data (McCabe et al. 1984, Roval et al. 1990), the duration of the complete intracellular cycle is about six days. Only RAL strain lasts more time to complete its development into J774 macrophages.

The resistance of $T$. cruzi to chemotherapeutic drugs varies from $0 \%$ to $100 \%$ (Filardi \& Brener 1984) and it has been related to miotropic preferences of strains and predominance of broad blood forms, while sensitive strains are miotropic or reticulotropic, showing predominance of slender forms (Melo \& Brener 1978, Andrade et al. 1985, Neal \& Van Bueren 1988). Some aspects as variations in absorption and metabolism of drug, incorporation to different infected tissues, synergic intervention of immune system as well as clinic 


\section{TABLE I}

Susceptibility of Trypanosoma cruzi epimastigotes to nifurtimox, benznidazole and gentian violet expressed as reduction percentages $(\% \mathrm{R})$ and growth percentages $(\% \mathrm{G})$ regarding untreated controls

\begin{tabular}{lrcccccccccc}
\hline & & \multicolumn{3}{c}{ Bolivia strain } & \multicolumn{2}{c}{ RAL strain } & \multicolumn{2}{c}{ GM strain } & \multicolumn{2}{c}{ MC strain } & \multicolumn{2}{c}{ Y strain } \\
\cline { 3 - 12 } Compound & Concentration & $\% \mathrm{R}$ & $\% \mathrm{C}$ & $\% \mathrm{R}$ & $\% \mathrm{C}$ & $\% \mathrm{R}$ & $\% \mathrm{C}$ & $\% \mathrm{R}$ & $\% \mathrm{C}$ & $\% \mathrm{R}$ & $\% \mathrm{C}$ \\
\hline Nifurtimox & $100 \mu \mathrm{g} / \mathrm{ml}$ & 98.2 & 0 & 100 & 0 & 98.1 & 0 & 99.1 & 0 & 100 & 0 \\
& $10 \mu \mathrm{g} / \mathrm{ml}$ & 90.9 & 0 & 82.5 & 0 & 89.5 & 0 & 87.9 & 0 & 9.9 & 0 \\
& $1 \mu \mathrm{g} / \mathrm{ml}$ & 0 & 82.5 & 0 & 82.1 & 0 & 80.9 & 0 & 87,3 & 0 & 58.1 \\
& $0.1 \mu \mathrm{g} / \mathrm{ml}$ & 0 & 93.4 & 0 & 103.6 & 0 & 91.8 & 0 & 91,9 & 0 & 82.3 \\
Benznidazole & $0.01 \mu \mathrm{g} / \mathrm{ml}$ & 0 & 100 & 0 & 118.6 & 0 & 100 & 0 & 103,4 & 0 & 96.5 \\
& $100 \mu \mathrm{g} / \mathrm{ml}$ & 84.7 & 0 & 100 & 0 & 81.8 & 0 & 97.2 & 0 & 100 & 0 \\
& $10 \mu \mathrm{g} / \mathrm{ml}$ & 0 & 60.7 & 0 & 63.2 & 0 & 65.4 & 0 & 42,2 & 48.3 & 0 \\
& $1 \mu \mathrm{g} / \mathrm{ml}$ & 0 & 77.4 & 0 & 101.3 & 0 & 75 & 0 & 70,3 & 0 & 88.7 \\
& $0.1 \mu \mathrm{g} / \mathrm{ml}$ & 0 & 84 & 0 & 120.5 & 0 & 85.7 & 0 & 80 & 0 & 122.5 \\
Gentian violet & $0.01 \mu \mathrm{g} / \mathrm{ml}$ & 0 & 91.3 & 0 & 112.4 & 0 & 95.7 & 0 & 94,6 & 0 & 120.2 \\
& $100 \mu \mathrm{g} / \mathrm{ml}$ & 100 & 0 & 100 & 0 & 100 & 0 & 100 & 0 & 100 & 0 \\
& $10 \mu \mathrm{g} / \mathrm{ml}$ & 71.8 & 0 & 75.4 & 0 & 67.2 & 0 & 88.2 & 0 & 82.4 & 0 \\
& $1 \mu \mathrm{g} / \mathrm{ml}$ & 0 & 40.4 & 0 & 32.4 & 0 & 39.8 & 0 & 31,9 & 75.8 & 0 \\
& $0.1 \mu \mathrm{g} / \mathrm{ml}$ & 0 & 97.4 & 0 & 5.8 & 0 & 92.3 & 0 & 56,8 & 0 & 71.4 \\
& $0.01 \mu \mathrm{g} / \mathrm{ml}$ & 0 & 101.6 & 0 & 87 & 0 & 120 & 0 & 81,4 & 0 & 86.8 \\
\hline
\end{tabular}

TABLE II

Metacyclogenesis process of Trypanosoma cruzi strains after seeding supernatants from LIT in Grace medium. The numbers of morphological types were determined by differential counting of Giemsa stained smears

\begin{tabular}{|c|c|c|c|c|c|c|c|c|}
\hline \multirow[b]{2}{*}{$\underline{\text { Strain }}$} & & \multicolumn{7}{|c|}{ Days } \\
\hline & & 2 & 4 & 7 & 9 & 11 & 14 & 16 \\
\hline Bolivia & $\begin{array}{l}a \\
b \\
c\end{array}$ & $\begin{array}{c}92.5 \\
3.5 \\
4\end{array}$ & $\begin{array}{l}75 \\
14.5 \\
10.5\end{array}$ & $\begin{array}{l}55 \\
17.5 \\
27.5\end{array}$ & $\begin{array}{l}53.8 \\
13.3 \\
33\end{array}$ & $\begin{array}{l}57.8 \\
14 \\
28.3\end{array}$ & $\begin{array}{l}62 \\
11 \\
27\end{array}$ & $\begin{array}{l}60.3 \\
12 \\
27.8\end{array}$ \\
\hline RAL & $\begin{array}{l}a \\
b \\
c\end{array}$ & $\begin{array}{c}87.25 \\
10.75 \\
2\end{array}$ & $\begin{array}{r}79.3 \\
15.5 \\
8.8\end{array}$ & $\begin{array}{r}72.8 \\
18.5 \\
8.8\end{array}$ & $\begin{array}{l}60.5 \\
27 \\
12.5\end{array}$ & $\begin{array}{l}67.3 \\
19 \\
13.8\end{array}$ & $\begin{array}{l}74 \\
14.5 \\
11.5\end{array}$ & $\begin{array}{l}73.5 \\
13.8 \\
12.8\end{array}$ \\
\hline GM & $\begin{array}{l}a \\
b \\
c\end{array}$ & $\begin{array}{l}71.5 \\
10.75 \\
17.75\end{array}$ & $\begin{array}{r}69.3 \\
7.5 \\
23.3\end{array}$ & $\begin{array}{l}51.5 \\
13.5 \\
35\end{array}$ & $\begin{array}{l}43.8 \\
16.3 \\
40\end{array}$ & $\begin{array}{c}44 \\
9.5 \\
46.5\end{array}$ & $\begin{array}{l}49 \\
14.5 \\
36.5\end{array}$ & $\begin{array}{l}41.3 \\
10.5 \\
48.3\end{array}$ \\
\hline $\mathrm{MC}$ & $\begin{array}{l}a \\
b \\
c\end{array}$ & $\begin{array}{l}88 \\
10.25 \\
1.75\end{array}$ & $\begin{array}{r}89.8 \\
7.8 \\
2.5\end{array}$ & $\begin{array}{r}85.8 \\
10.8 \\
3.5\end{array}$ & $\begin{array}{r}75.5 \\
18.3 \\
6.5\end{array}$ & $\begin{array}{c}77.3 \\
16.8 \\
6\end{array}$ & $\begin{array}{r}76 \\
15.8 \\
8.3\end{array}$ & $\begin{array}{r}87.3 \\
12.8 \\
7.5\end{array}$ \\
\hline Y & $\begin{array}{l}a \\
b \\
c\end{array}$ & $\begin{array}{l}83 \\
13.5 \\
3.5\end{array}$ & $\begin{array}{l}84.3 \\
11 \\
4.8\end{array}$ & $\begin{array}{l}78.8 \\
15 \\
6.3\end{array}$ & $\begin{array}{l}63.5 \\
22.5 \\
14\end{array}$ & $\begin{array}{l}66.8 \\
21.2 \\
11.5\end{array}$ & $\begin{array}{l}76.3 \\
13.3 \\
10.5\end{array}$ & $\begin{array}{l}79 \\
10 \\
11\end{array}$ \\
\hline
\end{tabular}

$a: \%$ epimastigote forms; $b: \%$ intermediate forms; $c: \%$ trypomastigote forms

phase of infection or morphological stage can be implicated (De Castro \& De Meirelles 1987, Toledo et al. 1990).

However, most authors think that success of the treatment depends mainly on the strain of $T$. cruzi (Brener \& Chiari 1967, Habekorn \& Gonert 1972, Andrade et al. 1975, Brener et al. 1976, Andrade \& Figueira 1977, Filardi \& Brener 1990). By this reason, we assessed the susceptibility as- says directly on the parasite, employing axenic cultures of epimastigote forms in LIT medium. Nifurtimox and benznidazole showed a trypanocide activity of $100 \%$ at $100 \mu \mathrm{g} / \mathrm{ml}$ against two strains ( $\mathrm{Y}$ and RAL). The former one is also the most sensitive to benznidazole and gentian violet. Previous data about in vivo assays with nifurtimox and benznidazole against $\mathrm{Y}$ strain (Ribeiro et al. 1988) also reported it as more sensitive (35 and 
$57 \%$ of cure, respectively) than Bolivia strain (0 and $18 \%)$. So, Y strain becomes a good candidate for primary screening of new potential tripanocide agents.

After all, the interest of the biological characterization of $T$. cruzi strains by classical procedures remains, because it contributes with interesting data and it is an important help for our understanding of Chagas disease.

\section{REFERENCES}

Allaoui A, François C, Zemzoumi K, Guilvard E, Ouaissi A 1999. Intracellular growth and metacyclogenesis defects in Trypanosma cruzi carrying a targeted deletion of a TC52 protein-encodin allele. Mol Microbiol 32: 1273-1286.

Andrade SG, Figueira RM 1977. Estudo experimental sobre ação terapêutica da droga Ro 7-1051 na infecção por diferentes cepas do Trypanosoma cruzi. Rev Inst Med Trop São Paulo 19: 335-341.

Andrade SG, Figueira RM, Carvalho ML, Gorini DF 1975. Influência da cepa do Trypanosoma cruzi na reposta à terapêutica experimental pelo Bay 2502. Rev Inst Med Trop São Paulo 17: 330-339.

Andrade SG, Magalhães JB, Pontes, AL1985. Evaluation of chemotherapy with benznidazole and nifurtimox in mice infected with Trypanosoma cruzi strains of different types. Bull WHO 63: 721-726.

Atienza J 1994. Cribado farmacológico contra Trypanosoma (Schizotrypanum) cruzi Chagas, 1909, PhD, Thesis, Universidad Complutense de Madrid, 436 pp.

Barbosa W, Czerewuta AC, Barbosa CA, Olivera OS 1988. Nota sobre a variação do comportamento da patogenicidade e imunogenicidade de cepas de Trypanosoma cruzi variedade hastatus e Y mutante após longo periodo de manutenção em cultura. Rev Patol Trop 17: 1-8.

Brener Z 1980. Immunity to Trypanosoma cruzi. Adv Parasitol 18: 247-292.

Brener Z, Chiari E 1967. Susceptibilidades de diferentes amostras de Trypanosoma cruzi a vários agentes quimioterápicos. Rev Inst Med Trop São Paulo 9: 197-207.

Brener Z, Costa CA, Chiari E 1976. Differences in the susceptibility of Trypanosoma cruzi to active chemotherapeutic agents. Rev Inst Med Trop São Paulo 11: $245-249$.

Carreño H, Rojas C, Aguilera X, Apt N, Miles MA, Solari A 1987. Schizodeme analysis of Trypanosoma cruzi zymodemes from Chile. Exp Parasitol 64: 252260.

De Castro SL, De Meirelles MN 1987. Effect of drugs on Trypanosoma cruzi and on its interaction with heart muscle cell "in vitro". Mem Inst Oswaldo Cruz 82: 209-218.

Fernandez-Gomez R, Esteban S, Gomez-Corvera R, Kherrouche Z, Ouaissi A 1998. Trypanosoma cruzi: Tc52 released protein-induced increased expression of nitric oxide synthase and nitric oxide production by macrophages. J Immunol 160: 3471-3479.
Filardi SL, Brener Z 1984. A rapid method for testing "in vivo" the susceptibility of different strains of Trypanosoma cruzi to active of chemotherapeutic agents. Mem Inst Oswaldo Cruz 79: 221-225.

Filardi LS, Brener Z 1990. Results of specific treatment with benznidazole in mice at the acute and chronic phase of Trypanosoma cruzi infection. Mem Inst Oswaldo Cruz 85: 99.

Funayama GK, Prado Junior JC 1974. Estudo sobre os caracteres de una amostra boliviana do Trypanosoma cruzi . Rev Soc Bras Med Trop 8: 75-81.

Grace TDC 1962. Establishment of four strains of cells from insect tissue growth in vitro. Nature 195: 788789.

Habekorn A, Gonert R 1972. Animal experimental investigation into the activity of nifurtimox against Trypanosoma cruzi. Arznein Forsch 22: 1570-1581.

Herrero A, Ochoa C, Atienza A, Escario JA, Gómez Barrio A, Martínez Fernández AR 1992. Synthesis and antiprotozoal properties of 1,2,6-thiadiazine 1,1dioxide derivates. Arch Pharm (Weinheim) 325: 504514.

Kagan IG, Norman L, Allain D 1966. Studies on Trypanosoma cruzi isolated in the United States: a review. Rev Biol Trop 14: 55-73.

Ley V, Andrews NW, Robbins ES, Nussenzweig NW 1988. Amastigotes of Trypanosoma cruzi sustain an infective cycle in mammalian cells. J Exp Med 168. 649-659.

McCabe RE, Remington JS, Araujo F 1984. Mechanisms of invasion and replication of the intracellular stage in Trypanosoma cruzi. Infect Inmunol 46: 372-376.

Melo RC, Brener Z 1978. Tissue tropism of different Trypanosoma cruzi strains. J Parasitol 64: 475-482.

Miles MA, Lanham SM, Souza AA, Póvoa M 1980. Further enzymic characters of Trypanosoma cruzi and their evaluation for strain identification. Trans $R$ Soc Trop Med Hyg 74: 221-237.

Miles MA, Souza A, Povoa M, Shaw JJ, Lainson R, Toye P 1978. Isoenzymic heterogeneity of Trypanosoma cruzi in the first autochtonous patients with Chagas' disease in Amazonian Brazil. Nature 272: 819-821.

Montamat EE, Durand S, Bocco JL, De Luca D’Oro GM, Blanco A 1999. Identification of Trypanosoma cruzi zymodemes by kinetoplast DNA probes. $J E u k$ Microbiol 46: 155-159.

Morel CM, Chiari E, Plessman Camargo E, Matte, DM, Romanha AJ, Simpson L 1980. Strains and clones of Trypanosoma cruzi can be characterized by pattern of restriction endonuclease products of kinetoplast DNA minicircles. Proc Natl Acad Sci USA 77: 6810-6814.

Neal RA, Van Bueren J 1988. Comparative studies of drug susceptibility of five strains of Trypanosoma cruzi "in vivo" and "in vitro". Trans $R$ Soc Trop Med Hyg 82: 709-714.

Osuna Carrillo A, Jimenez Ortiz A, Lozano Maldonado J 1979. Medios de cultivo para la obtención de formas metacíclicas de Trypanosoma cruzi. Rev Ibér Parasitol 39: 129-133.

Ouaissi A, Dubremetz JF, Schoneck R, Fernandez- 
Gomez R, Gomez-Corvera R, Billaut-Mulot O, Taibi A, Loyens M, Tartar A, Sergheraert C, Kusnierz JP 1995a. Trypanosoma cruzi: a 52-kDa protein sharing homologywith glutatione $\mathrm{S}$-transferase is localized in parasite organelles morphologically resembling reservosomes. Exp Parasitol 81: 453-461.

Ouaissi A, Guevara-Espinoza A, Chabé F, FernandezGomez R, Taibi A 1995b. A novel and basic mechanism of immunosuppression in Chagas' disease: Trypanosoma cruzi releases in vitro and in vivo a protein which induces unresponsiveness of $\mathrm{T}$ cells through specific interaction with cysteine and glutathione. Immunol Lett 48: 221-224.

Prado Junior JC, Ribeiro RD, Albuquerque S, Carraro AA, Lopes RA, García TAR, Toldo MA 1992a. Infecção natural do Gato do Mato, Felis yagouaroundi, pelo Trypanosoma cruzi. $14^{\circ}$ Encontro de Pesquisas Veterinárias (UNESP), p. 247.

Prado Junior JC, Ribeiro RD, Albuquerque S, Carraro AA, Lopes RA, García MAR 1992b. Natural infection of Guará, Chrysocyon brachyurus, by Trypanosoma cruzi. $14^{\circ}$ Encontro de Pesquisas Veterinárias (UNESP), p. 246.

Ready PD, Miles MA 1980. Delimination of Trypanosoma cruzi zymodemes by numerical taxonomy. Trans $R$ Soc Trop Med Hyg 74: 238-242.

Ribeiro RD, Albuquerque S, Carraro AA, Lopes RA, Prado Junior JC, García TAR, Toldo MPA 1993. Uma nova cepa do Trypanosoma cruzi isolada do triatomíneo Triatoma infestans. $45^{\circ}$ Reunião da SBPC, p. 769.

Ribeiro RD, Albuquerque S, Carraro TA, Rissato TA 1988. Índice de cura de camundongos tratados com nifurtimox e benzonidazol na doença de Chagas experimental. Rev Cien Farm S Paulo 10: 71-76.

Roval LE, Aoki A, Gerez de Burgos NM, Blanco A 1990.
Effect of Gossypol on trypomastigotes and amastigotes of Trypanosoma cruzi. J Protozool 37: 280-286.

Schenkman S, Andrews NW, Nussenzweig W, Robbins ES 1988. Trypanosoma cruzi invade a mammalian epithelial cell in a polarized manner. Cell 55: $157-$ 165.

Silva LH, Nussenzweig V 1953. Sobre uma cepa de Trypanosoma cruzi virulenta para o camundongo branco. Folia Clin Biol 20: 191-207.

Solari A, Muñoz S, Venegas J, Wallace A, Aguilera X, Apt W, Brèniere SF, Tibayrenc M 1992. Characterization of Chilean, Bolivian and Argentinian Trypanosoma cruzi populations by restriction endonuclease and isozyme analysis. Exp Parasitol 75: 187-195.

Steindel M, Dias Neto E, De Menezes CLP, Romanha AJ, Simpson AJG 1993. Random amplified polymorphic DNA analysis of Trypanosoma cruzi strains. Mol Biochem Parasitol 60: 71-80.

Tibayrenc M, Ayala F 1987. Forte correlation entre classification isoenzymatique et variabilité de l'ADN kinetoplastique chez Trypanosoma cruzi. Comp Rend S Acad Sci Paris 304: 89-92.

Tibayrenc M, Ayala F 1988. Isoenzyme variability in Trypanosoma cruzi, the agent of Chagas' disease: genetical, taxonomic and epidemiological significance. Evolution 42: 277-292.

Tibayrenc M, Ward P, Moya A, Ayala F 1986. Natural populations of Trypanosoma cruzi, the agent of Chagas' disease, have a complex multiclonal structure. Proc Natl Acad Sci USA 83: 115-119.

Toledo MJO, Pereira MES, Brener Z 1990. Effects of immunosupression on the specific treatment of mice experimentally infected with Trypanosoma cruzi. Mem Inst Oswaldo Cruz 85: 100.

WHO 1991. Control of Chagas' disease. WHO Technical Report, Series No. 811, Geneva. 